\title{
Further notes on Nymphaea (Nymphaeaceae) in Australasia
}

\author{
S.W.L. Jacobs
}

\begin{abstract}
Jacobs, S.W.L. (National Herbarium of New South Wales, Royal Botanic Gardens, Sydney NSW Australia 2000) 1994. Further notes on Nymphaea (Nymphaeaceae) in Australasia. Telopea 5(4): 703-706. Nymphaea nouchali is accepted as the correct name for what has been known as $N$. minima. The name $N$. nouchali has also been applied to another widespread African, Indian and SE Asian species, the earliest name for which is $N$. caerulea. The combination N. caerulea subsp. zanzibarensis is made for the taxon naturalised on the east coast of Australia formerly known as $N$. capensis. Attention is drawn to a localised unusual form of $N$. pubescens that lacks one of the main diagnostic characters.
\end{abstract}

\section{Introduction}

The delay in publication of the 'Flora of Australia' volume containing the family Nymphaeaceae allows the results of further studies to be published as a precursor paper additional to Jacobs (1992). A fuller account is planned of other aspects, including scanning electron micrographs of the seeds of at least all the native species.

\section{Nymphaea minima, $\boldsymbol{N}$. nouchali and $\boldsymbol{N}$. caerulea}

Bailey (1883) described N. minima from a specimen collected near Cairns. Unfortunately there was an earlier homonym, N. minima Reichenbach (1830), now regarded as referable to a species in Nuphar. Bailey's species, however, is the same as Nymphaea nouchali Burm. f., as indicated indirectly by van Royen (1962) who included specimens of Bailey's species under $N$. nouchali, although his species circumscription was much wider, including the names N. stellata Willd. and N. caerulea Savigny in N. nouchali. Verdcourt (1989) followed van Royen's use of N. nouchali. Specimens previously referred to $N$. nouchali fall into two groups and I consider these warrant specific recognition.

The first species includes the type of $N$. nouchali and the generally smaller plants, where the flowers are held at or just above the water surface, with fewer and comparatively tougher (though still quite membranous) filaments and generally shorter, blunter, flattened (sometimes more or less cylindrical) sterile anther appendages that are usually less than $25 \%$ the length of the anther on the outermost stamens, and seeds with rows of comparatively long, dense hairs. The Type is a partly decomposed flower mounted with a leaf belonging to a species from a completely different family. The petals and stamens are still visible though the ovary is badly decomposed. The specimen is not easy to relate to living material but the comparatively tougher anther filaments and the short anther appendages indicate that it represents this species. The drawings in van Royen (1962) are good representations of the normal situation in this species but are not particularly good renditions of the Type where the appendages are rather more cylindrical than usual. A description is supplied here based on Australasian collections to clarify my application of the name. 
The second species previously also referred to $N$. nouchali includes the frequently larger-growing plants with clearly emergent flowers standing well clear of the water, with comparatively more delicate and membranous but flattened filaments and usually acute, more or less cylindrical sterile anther appendages that are normally at least $30 \%$ as long as (often equal to) the anther on the outer stamens, and whose seeds have rows of comparatively short hairs that may be quite sparse. Names extensively used in cultivation, viz. $N$. caerulea Savigny (the earliest name for the group), $N$. stellata auct. non Willd. (N. stellata Willd. = N. nouchali s. str.) and N. capensis Thunb. are all referable to this species. I agree with van Royen (1962) and Verdcourt (1989) who regard all of these names as referable to the one species but, as stated by Verdcourt, there are sufficient differences to warrant recognition of some of these variants below the species level. The combination $N$. caerulea subsp. zanzibarensis is made below as the name is required for use in Australia where the taxon is naturalised and widespread on the east coast. This taxon is geographically distinct in its natural habitat and can be distinguished from the other subspecific taxa in this species by its sinuate leaf margins and non-raised leaf venation on the undersurface (Verdcourt 1989). It has also been noted to breed true over several generations (Verdcourt 1989). Because of the distinct leaf characters, their lack of variation, the lack of discontinuity in floral or fruit characters, and the geographical discontinuity in the distributions, subspecies is the relevant category for this taxon. Understanding taxa in Nymphaea requires considerable field studies and, as I have not studied all of these in the field, I am not in a position to comment on the status of the other taxa that grow elsewhere in the world, so the relevant combinations will need to be made by someone more familiar with those taxa.

\section{Nymphaea nouchali Burm. f.}

(Burman 1768: 120)

Holotype: India: Coromandel, Outgaerden (G: photograph NSW). Drawing in van Royen (1962).

N. minima F.M. Bailey (1883: 10) non Reichenbach (1830: 14), syn. nov.

Holotype: Australia: QueENSLAND: Still waters off Barron River, F.M. Bailey (BRI 278799).

Annual or perennial aquatic herb with erect rhizome to $\mathrm{c} .3 \mathrm{~cm}$ diam. Blade usually floating, orbicular, usually to $10 \mathrm{~cm}$ diam., rarely to c. $23 \mathrm{~cm}$ diam., with a radial slit to the centre or to within $6 \mathrm{~mm}$ of the centre, lobes usually not overlapping; margins slightly sinuate. Flowers barely emergent; peduncle to $7 \mathrm{~mm}$ diam. at base. Sepals 4 , usually to $3 \mathrm{~cm}$ long, rarely to $7 \mathrm{~cm}$ long, green outside with purple streaks usually near the margins, tip acute. Petals up to c. 10, lanceolate, blue, pink or white, tip acute, with a gap between the petals and stamens. Stamens up to c. 20; filaments flattened and tough, to $11 \mathrm{~mm}$ long, usually shorter; anthers to $8 \mathrm{~mm}$ long; loculi separated by connective tissue; sterile appendage apical, to $7 \mathrm{~mm}$, usually less than $25 \%$ the length of the anther, usually flattened. Ovary lobed; carpels 7 to 8 : fruit small, c. $1.5 \mathrm{~cm}$ diam., rarely to $4 \mathrm{~cm}$ diam.; seeds spherical, c. $0.75 \mathrm{~mm}$ diam., with continuous rows of long hairs, cells of the testa having a long lumen and short arms, the ends neither expanded nor raised.

Selected specimens seen: Australia: Queensland: Camping Reserve R 12 (Bloomfield), Hyland 7315, 17 June 1974 (BRI); Wonga Beach $\mathrm{N}$ of Mossman, Jacobs 4887 E Sainty 3 May 1986 (NSW); Cairns, Jacobs 4825, 4826a E Sainty, 30 April 1986 (NSW); foot of Mt Cook, Scarth-Johnson $724 A$ Feb 1978 (BRI); Edmund Kennedy National Park, c. 6 km N of Cardwell, Thorsborne $517 \mathcal{E}$ Travers, 30 Apr 1979 (BRI). NORTHERN TERRITORY: Millingimbi floodplain, Clark 2245, 16 May 1990 (NSW, DNA); Mary River floodplain, Dunlop $7069 \mathcal{E}$ Wightman, 16 May 1987 (NSW, DNA, CANB, BRI, AD, PERTH, MEL, K, L); Bulls Run Creek, Tipperary Station, Leach 2855 E Cowie, 
4 May 1990 (NSW, DNA, CANB, MEL). PAPUA New Guinea: $1 \mathrm{~km}$ SW of Agevairu Store, Jacobs 5953 \& Conn, 19 Sept 1990 (NSW, LAE, UPNG).

BEHAVIOUR: Growing in temporary water bodies, swamps and pools. Flowering during the warmer months. Flowers open during the day.

There are two colour forms of this species in Australasia. Over most of their range they grow in the same areas, though populations are mostly of a single colour. Because of the unreliability of flower colour as a taxonomic character in Nymphaea, further characters will need to be found before these forms can be treated formally at any other level.

The most common in Australia is the blue-flowered form (rarely white), which is native on the coast from Cardwell north and west to near Darwin, often growing not far behind the mangroves. It also grows in New Guinea, Indonesia, SE Asia, and India.

The pink-flowered form, sometimes with white flowers, is common in New Guinea, often has considerably larger leaves and flowers than the blue-flowered form, and is usually found further from the coast. It grows naturally in, and has been recorded from, Indonesia, SE Asia and India (van Royen 1962; Verdcourt 1989). It has also been recorded from the Northern Territory, possibly as an adventive.

Nymphaea caerulea Savigny subsp. zanzibarensis (Caspary) S.W.L. Jacobs, comb. et stat. nov.

BASIONYM: N. zanzibarensis Caspary, Bot. Zeitung (Berlin) 35:203 (1877).

TYPE: specimens cultivated at Königsberg from seed sent from Zanzibar by Hildebrandt [no. 901] (B!).

N. capensis var. zanzibarensis (Caspary) Conard (1905: 157)

N. nouchali var. zanzibarensis (Caspary) Verdcourt (1989: 10)

This subspecies is naturalised and common on the east coast of Australia, south from the tropic to just south of Sydney. It has generally been called N. capensis Thunb. here.

\section{Nymphaea pubescens}

N. pubescens Willd. grows in India, SE Asia, the Philippines, Papua New Guinea, is reasonably common near the coast in the Northern Territory, and grows spasmodically on the east coast of Queensland. The population along Magela Creek in the Northern Territory differs from all the other Australasian populations in having the abaxial leaf surface glabrous instead of pubescent. The Magela Creek population matches the other populations in all other respects. Attention is drawn to this variant because the pubescent abaxial leaf surface is one of the key characters for distinguishing N. pubescens from other closely related species such as N. lotus L. and N. nouchali. $N$. pubescens is at one limit of its distribution in Australia and while this glabrous variant could be recognised at a rank below species level there are too few collections from a wide enough range of localities to do so with any confidence at present. As $N$. pubescens is a comparatively mobile species of Nymphaea, this form may be found elsewhere. It is hoped that highlighting this problem will encourage further collections. 


\section{Acknowledgements}

Thanks to Karen Wilson for helpful discussion and photographs of the Type of Nymphaea nouchali, Jocelyn Powell for useful comments on the manuscript, and Bernard Verdcourt for helpful comments in his referee's report.

\section{References}

Bailey, F.M. (1883) A synopsis of the Queensland flora.

Burman, N.L. (1768) Flora Indica.

Caspary, J.X.R. (1877) Nymphaea zanzibarensis n. sp. Botanische Zeitung (Berlin) 35: 200-203.

Conard, H.S. (1905) The waterlilies. (Carnegie Institute: Washington).

Jacobs, S.W.L. (1992) New species, lectotypes and synonyms of Australasian Nymphaea (Nymphaeaceae). Telopea 4: 635-641.

Reichenbach, H.G.L. (1830) Flora Germanica excursaria, part 1. (Leipzig).

Royen, P. van (1962) Sertulum Papuanum 5, Nymphaeaceae. Nova Guinea 8: 103-126.

Verdcourt, B. (1989) Nymphaeaceae, in R.M. Polhill (ed.), Flora of Tropical East Africa. (Royal Botanic Gardens; Kew).

Manuscript received 14 May 1993

Manuscript accepted 4 February 1994 